\title{
A kiégés és a depresszió diagnosztizálásának elősegítése demográfiai és munkahelyi védő- és kockázati tényezőinek feltárásával egészségügyi szakdolgozók körében
}

\author{
Ádám Szilvia dr. ${ }^{1}$ - Nistor Anikó ${ }^{1}$ - Nistor Katalin ${ }^{1}$ \\ Cserháti Zoltán dr. ${ }^{1}$ - Mészáros Veronika dr. ${ }^{2}$ \\ ${ }^{1}$ Semmelweis Egyetem, Általános Orvostudományi Kar, ${ }^{1}$ Magatartástudományi Intézet, \\ ${ }^{2}$ Klinikai Pszichológiai Tanszék, Budapest
}

\begin{abstract}
Bevezetés: A depresszió és a kiégés gyakran lép fel együtt egészségügyi szakdolgozók körében. Bár tüneteik hasonlóak, kezelésük eltérő, így mihamarabbi felismerésük rendkívül fontos. Célkitüzés: A kiégés és a depresszió demográfiai és munkahelyi rizikó-, valamint védőtényezőinek feltárása és diagnosztizálásuk elősegítése. Módszer: A depressziót a rövidített Beck Depresszió Kérdőívvel, a kiégést a Maslach Kiégés Leltárral mérték 1713 egészségügyi szakdolgozó körében keresztmetszeti adatfelvétellel. A kockázati és védőtényezőket $t$-próbával és varianciaanalízissel tárták fel. Eredmények: A depresszió és a legalább közepes szintű kiégés prevalenciája egyenként 35,1\% és 34-74\% volt. A partner/gyermek megléte, a hosszabb, valamint a járóbeteg-ellátásban való munkaviszony a kiégés védőtényezőjének bizonyult. A partner hiánya és a férfi nem egyenként a depresszió és a deperszonalizáció kockázati tényezőjeként jelent meg. Következtetések: A depresszió és a kiégés magas prevalenciája egészségügyi szakdolgozók körében jelentős közegészségügyi probléma. A két tünetegyüttes kutatásunkban feltárt kockázati és védőtényezőinek ismerete megkönnyítheti időben történő diagnosztizálásukat és hatékony kezelésüket.Orv. Hetil., 2015, 156(32), 1294-1303.
\end{abstract}

Kulcsszavak: kiégés, depresszió, egészségügyi szakdolgozók, rizikótényezők, védőtényezők

Facilitating the diagnosis of depression and burnout by identifying demographic and work-related risk and protective factors among nurses

\begin{abstract}
Introduction: Depression and burnout are frequent comorbidities among nurses. Despite similar symptoms, their management differ. Therefore, their timely diagnosis is essential. Aim: To identify demographic and work-related risk and protective factors of burnout and depression, and facilitate their diagnosis. Method: A cross-sectional study among 1,713 nurses was carried out. Depression and burnout were assessed by the shortened Beck Depression Questionnaire and Maclach Burnout Inventory, respectively. Risk and protective factors were explored using $t$-tests and analysis of variance. Results: The prevalence of depression and moderate-to-high burnout was $35.1 \%$ and $34-74 \%$, respectively. Having a partner/child and longer employment in the outpatient setting protected from burnout. Lack of a partner and male sex emerged as risk factors of depression and depersonalisation, respectively. Conclusions: High prevalence of depression and burnout among nurses poses a significant public health issue. Familiarity with the disease-specific risk and protective factors identified in this research may facilitate timely diagnosis and effective disease management.
\end{abstract}

Keywords: burnout, depression, nurses, risk factors, protective factors

Ádám, Sz., Nistor, A., Nistor, K., Cserbáti, Z., Mészáros, V. [Facilitating the diagnosis of depression and burnout by identifying demographic and work-related risk and protective factors among nurses]. Orv. Hetil., 2015, 156(32), 1294-1303.

(Beérkezett: 2015. május 26., elfogadva: 2015. június 25.) 
A kiégés és a depresszió közötti kapcsolat már hosszú évtizedek óta a foglalkozás-egészségtan egyik legintenzívebben vizsgált kérdése külföldön $[1,2]$. A kiégést több kutató a depresszió egyik korai (közvetett) indikátoraként tartja számon $[1,3,4,5]$. Az erőforrás-konzervációs elmélet (conservation of resources theory) szerint mind a kiégés, mind a depresszió megterhelő helyzetekre adott érzelmi válasz $[3,4]$. Megterhelő helyzetekben az egyén eleinte képes aktívan küzdeni és szembenézni az őt fenyegető hatásokkal. A hosszan tartó aktív megküzdés azonban kimerítheti érzelmi energiáját és viselkedése távolságtartóvá válik, teljesítménye csökken. Ez a kiégés állapota. A kiégés jellemzője, hogy elsősorban a munkavégzéshez kapcsolódó energiatartalékok felemésztése történik. Ha a megterhelő helyzet krónikussá válik, az alacsony energetikai állapot nemcsak a munkára, hanem az élet minden területére kiterjedhet, ami pedig már depressziós tüneteket okozhat. E modell szerint a kiégés az úgynevezett másodlagos emberi erőforrások apadásához köthető, amelyeknek az egyén versenyképességében, növekedési potenciáljában van fontos szerepe (például a munkavégzés minősége). Ezzel szemben a depresszióban szenvedőknél az emberi lét elsődleges, alapvető erőforrásai (például biztonság, élelemszerzés képessége) merülnek ki. E modell tehát a kiégést enyhébb, a depressziót súlyosabb állapotként definiálja és elkülöníti a kiégésben nem szenvedő, a kiégésben szenvedő, valamint a depressziós állapotokat. Az erőforrás-konzervációs elméleten alapuló kiégés-depresszió folyamatot több empirikus vizsgálat alátámasztotta már $[1,5]$.

A kiégés egyéni, interperszonális és önértékeléshez kapcsolódó dimenzióval jellemezhető. Egyéni aspektusa az emocionális kimerülés, amely a fizikai és érzelmi fáradtság állapota. Interperszonális jellemzője a deperszonalizáció, azaz a másoktól való elidegenedés, amely közönyös, távolságtartó attitűddel jár. A személyes teljesit ményérzés hiánya az önértékelési aspektus, amely csökkent kompetenciaérzéssel, a produktivitás alacsony szintjével írható le [6] A kiégés két-, három-, négy-, illetve ötdimenziós modelljét is leírták. A magyar mintára a kétdimenziós modell jellemző, amely a három alskála öszszpontszáma mellett (az úgynevezett általános kiégés) a személyes teljesítményérzés hiányát tartja mérvadónak [7].

A depresszió - melankólia vagy búskomorság - olyan kedélybetegség, amelyre jellemző a tartós hangulatingadozás, a szomorúság, az érdeklődés és az öröm elvesztése, a bűntudat, az alacsony önértékelés, alvászavarok, étvágytalanság, a fáradtság és a gyenge koncentráció. A depresszió egyrészt lényegesen csökkenti az egyén képességét munkájának elvégzésére, másrészt megnehezíti azt, hogy az egyén megbirkózzon a mindennapi élet feladataival. A depresszió legsúlyosabb formájában igen gyakoriak az öngyilkossági gondolatok és maga az öngyilkossági kísérlet. A depresszió kialakulásában genetikai és környezeti tényezók játszanak szerepet [8]. A környezeti tényezők közül kiemelendő a magas munkahelyi követelmény, a munka feletti alacsony kontroll és a társas támogatás hiánya, amelyek a depresszió kialakulásának veszélyét szignifikánsan növelik [9].

A kiégés és a depresszió közötti kapcsolat feltárásához fontos megismerni a két kórállapot tüneteinek és patomechanizmusának hasonlóságait és különbségeit. A tünetek hasonlóságát tekintve megállapítható, hogy mindkét kórállapotra jellemző a mások problémáira adott érzelmi válaszok számának csökkenése, az empátiás kognícióról a nem empátiás kognícióra való átváltás $[10,11]$, a jelentős örömképtelenség, a szociális ingerektől való eltávolodás [12], az információk felidézésével, valamint a döntések meghozatalával kapcsolatos nehézségek [13]. Bár mindkét állapot alacsony alapaktivációs szinttel jár, az aktivációs szint csökkenése a kiégés esetében nem annyira markáns, mint a depresszió fennállásakor. A kiégésben szenvedő emberek vitálisabb benyomást keltenek, mint a depressziósok, ritkán veszítenek súlyúkból és mutatnak pszichomotoros lassulást [3]. Az egyes helyzetekhez kapcsolódó saját felelősségről is reálisabb elképzelésük van, emellett búntudatuk is kisebb, mint a depresszióval küzdőké [14]. A tünetek különbözőségét tekintve fontos különbség az is, hogy a kiégésben szenvedők számára csak a munkahelyi kapcsolatokban megjelenő kölcsönösség érzése sérül, míg a depressziósok összes intim kapcsolatukban hiányolják a viszonosság érzését [1]. Mindemellett elmondható az is, hogy a kiégés kifejezetten a munkahelyi környezethez kapcsolható, míg a depresszió kontextusfüggetlen és az élet minden területére - beleértve a munkahelyet is - kiterjed [10]. Összegezve a hasonlóságokat a tünetek tekintetében, a két jelenség rokonsága jól látható, a tüneti különbségek pedig rámutatnak arra, hogy a kiégés a depressziónál visszafogottabb, kevésbé éles körvonalakkal jellemezhető. Megerősítő faktoranalízisek felhasználásával számos kutató jutott arra a következtetésre, hogy a két kórállapot tüneteit tekintve nem ugyanannak a jelenségnek a manifesztációja, vagyis két elkülönülő jelenség [1].

A két kórállapot rizikó- és védőtényezőinek, manifesztációjának és lefolyásának vizsgálata is komplex képet mutatott. Számos vizsgálat számolt be a biológiai nem lehetséges védő- vagy súlyosbító szerepéről. A depreszszió - amelynek patogenezisében többek között a streszsz és a hormonális rendszer változásai is szerepet játszanak - nagyobb arányban fordul elő nőknél, mint férfiaknál. Ennek egyik oka lehet, hogy a nók hajlamosabbak a ruminációra (őrlődésre) - fokozott szintû́ hoszszan tartó stresszállapot -, valamint szervezetük hormonális egyensúlya is labilisabb, fóként menstruáció előtt, valamint menopauza idején $[15,16]$. A kiégés nemi különbségei tekintetében a nők nagyobb valószínúséggel mutatnak emocionális kimerültséget, míg a férfiak hajlamosabbak a deperszonalizációra. Ennek hátterében a két nem eltérő stresszmegküzdési stratégiái állhatnak. A nők könnyebben fejezik ki érzelmeiket, gyakrabban reagálnak a stresszes szituációkra érzelmi bevonódással, ami hamarabb vezethet érzelmi kimerüléshez, míg a férfiak 
inkább kivonják magukat a problematikus helyzetekből és ezért körükben a deperszonalizáció a gyakoribb [17].

Klinikai vizsgálatok eredményei szerint a házastárs vagy családtag megléte a depresszió egyértelmű védőtényezőjeként jelenik meg, ezek hiánya pedig rizikótényezőnek számít [18]. Míg a kiégés prevalenciáját és szintjét a házastárs és a gyermekek megléte ugyancsak csökkenti, a társ elvesztése - a depresszióval ellentétben - a kiégés szintjére és prevalenciájára nincs hatással $[19,20]$. Kifejezetten a kiégésre jellemző védőtényező a munkahelyen eltöltött hosszabb idő. Ennek két magyarázata közül az első az úgynevezett „reality shock” (a valósággal való szembesülés okozta sokk) elmélet, amely szerint a fiatal munkavállaló már akkor lelkesedését veszti, amikor munkahellyel kapcsolatos elvárásai nincsenek összhangban az állás által kínált lehetőségekkel. A másik magyarázat szerint, az idősebb munkavállalók közül azok hajlamosabbak válaszolni az önkitöltős tesztekre, akik rugalmasak, egészségesek - az úgynevezett „healthy worker effect” -, így mentális és egészségi mutatóik is kedvezőbbek fiatalabb kortársaikhoz viszonyítva [21]. A munkavállalás hosszából eredő megállapítások hozzák magukkal azt a feltételezést is, miszerint az idősebb munkavállalók kevésbé szenvednek kiégéstől [19]. Köztudott viszont, hogy a depresszió - a serdülőkor mellett - időskorban a leggyakoribb [16, 22], így a két jelenség ebben is megkülönböztethető egymástól. További vizsgálatok a szociodemográfiai és munkahelyi tényezők kiégéssel, valamint depresszióval való kapcsolatáról megerósítették azt a feltételezést, miszerint a két jelenségnek eltérő patogenetikai háttere van. A kiégés gyakoribb volt nők körében, azok között, akiknek hosszú munkaideje volt és fiatalabbak voltak, míg a depresszió olyan idősebb munkavállalók körében volt gyakoribb, akiket a munkatársak nem támogattak vagy segítettek [23].

A két kórállapot manifesztációjának és lefolyásának összehasonlítása számos figyelemre méltó eredményt hozott. Egy ápolók körében végzett kutatás szerint a kiégés és a depressziós tünetek párhuzamosan, de egymástól függetlenül alakultak ki [24]. Több vizsgálat viszont azt sugallta, hogy a kiégés depresszióvá, a depresszió pedig kiégéssé fejlődhet $[1,2]$. Ezen vizsgálatok eredményei részben alátámasztják az eróforrás-konzervációs elmélet feltevését, miszerint a kiégés a depresszió előfutára lehet. A kiégés vagy a depresszió tehát vagy önmagában, vagy egyidejűleg, de egymástól függetlenül is felléphet. Az esetek többségében azonban a két kórállapot összefonódik egymással, így tüneteik elkülönítése és ezáltal a kezelési stratégia kialakítása egy igazi klinikai kihívás.

Az Egészségügyi Világszervezet előrejelzése szerint a depresszió 2020-ra a második leggyakoribb munkaképesség-csökkenést okozó betegség lesz világviszonylatban. Magyarországon 1988 óta a klinikai szintű depreszszió gyakorisága folyamatosan nő. A Hungarostudy vizsgálatokból tudjuk, hogy a magyar populációban 1988-ban 7,5\%, 1995-ben 14,1\% és 2002-ben 16,5\% volt a depresszióban szenvedők aránya [25]. Az önbe- számolós módszerrel mérhető klinikai szintű depressziós tünetek az egészségügyben dolgozók 24-45\%-a körében van jelen [26]. A nemzetközi szakirodalom már az 1980as években rámutatott a munkahelyi stressz következtében kialakuló pszichés megbetegedések - köztük a kiégés - magas prevalenciájára egészségügyi szakdolgozók körében [6]. Magyarországi adatok alapján az ápolók 33,9\%-a kiégésveszélyben van, 5,5\%-a kiégésben szenved, $0,9 \%$-a pedig a kiégés mellett súlyos pszichiátriai megbetegedéssel is jellemezhető [27]. Kisebb mintával dolgozó vizsgálatok hasonló - 40-50\%-os - kiégési arányt publikálnak ebben a szakmában $[28,29]$.

Az egészségügyi szakdolgozók körében a kiégésnek és a depressziónak széles körú negatív hatásai vannak, amelyek nemcsak az egyén személyes és szakmai életét és kilátásait, hanem a betegellátás minőségét és az egészségügyi rendszer hatékonyságát is ronthatják [30]. Ezért a kiégés és a depresszió megelőzése és megfelelő kezelése az egészségügyi dolgozók körében kiemelkedően fontos. A két kórállapot felismerése és elkülönítése a gyakorlati orvoslásban azonban - a tünetek hasonlósága és a kórfolyamatok egymásba fonódása miatt - kihívásokkal teli. Ezt jól tükrözi az a tény, hogy a DSM-V (Diagnostic and Statistical Manual of Mental Disorders) magát a „kiégés" szót nem tartalmazza, tehát nem sorolja az önálló betegségek körébe, bár diagnosztikai kritériumok alapján beleillik a „pszichés egyensúly zavarai”-nak (mental adjustment disorders) kategóriájába. A kiégést azonban az ICD-10 (International Classification of Diseases) önálló betegségként könyveli el (Z73.0). Ezért jelen vizsgálatunk célja az volt, hogy segítsük a kiégés és a depreszszió felismerését a két tünetegyüttes demográfiai és munkahelyi rizikó- és védőtényezőinek a feltárásával egészségügyi szakdolgozók körében. A fent bemutatott tudományos eredmények alapján hipotéziseink a következők voltak:

$\mathrm{Hl}$ : A korábbi pszichés megbetegedés a kiégés és a depresszió rizikótényezője.

H2: A nók körében a depresszió és a kiégés prevalenciája, valamint szintje magasabb, mint férfiaknál.

H3: A partner hiánya vagy elvesztése a depresszió rizikótényezője.

H4: A partner megléte a kiégés védőtényezője.

H5: A hosszabb egészségügyi munkaviszony a kiégés védőtényezője.

H6: Az életkor és a depresszió között egyenes arányú kapcsolat van.

\section{Módszer}

\section{Minta}

A vizsgálat keretében 2500 kérdőívet osztottunk szét a fóváros 23 kerületében. A kérdőíveket a Magyar Egészségügyi Szakdolgozói Kamara (MESZK) területi szervezeteinek helyi vezetői juttatták el a szakdolgozókhoz. A kiküldött kérdőívekből 1732 érkezett vissza, amelyből 
19 hiányosan kitöltött volt. Így a vizsgálatban 1713 fó adatait elemeztük (68,5\%-os válaszarány). Az 1713 egészségügyi szakdolgozó közül 79 férfi (4,6\%) és 1634 nő $(95,4 \%)$ volt. Átlagéletkoruk 44,0 év (minimum: 20 év; maximum: 78 év; SD=10,0 év) volt. A kérdőívet kitöltők közül legtöbben 30-as (506 fö, 29,5\%) és 40-es (546 fó, 31,9\%) éveikben jártak. A minta a budapesti egészségügyi szakdolgozók körében reprezentatív az ellátási szint (alap, járó, fekvő, egyéb - például gyógyszertári asszisztensek, idősek otthonában dolgozók) tekintetében. Az 1. táblázatban összegeztük a vizsgálatban résztvevők demográfiai adatait

\section{Méröeszközök}

\section{Demográfiai változók}

Rákérdeztünk a kitöltők nemére, életkorára, családi állapotára, és gyermekeik, illetve az egészségügyben eltöltött éveik számára, korábbi pszichiátriai kezelésére, valamint a betegellátás szintjére.

\section{Kiégés}

A kiégést a Maslach Kiégés Leltárral mértük (Maslach Burnout Inventory-Human Services Survey - MBIHSS), amelyet Maslach és munkatársai kifejezetten a humán szolgáltatószektorban dolgozók kiégettségének vizsgálatára fejlesztették ki [31]. A kérdőív eredeti változata 22 tételt tartalmaz, a tételek megítélése 7 fokú skálán történik. A magyar változatban 21 tétel szerepel (a kérdőív összpontszáma a 4. tétel kiemelésével értelmezhető. A kiégés értelmezéséhez a 21 tétel összpontszáma mellett a személyes teljesítményérzés hiányát mérő skála átlagos pontszáma nyújt támogatást a magyar mintán [32]. Előbbi vizsgálatunk 0,87 , az utóbbi pedig 0,79 Cronbach-alfa-értékkel rendelkezett. A kérdőív másik két skálája az emocionális kimerülés és a deperszonalizáció magyar mintán nem hordoz többletinformációt, valamint magyar nyelvû standardjai sincsenek, ezért ezek mintában való eloszlását csak támpontként közöljük a kiégés gyakoriságának és eloszlásának szemléletesebb bemutatása érdekében [32].

\section{Depresszió}

A depresszió tüneteinek mérésére a 21 tételes Beck Depresszió Kérdőív [33, 34] 9 tételes rövidített változatát használtuk. A kérdőívet hazai mintán Rózsa, Szádóczky és Füredi érvényesítette [35]. A kérdőívbe a legmagasabb Cronbach-alfa-értékű 9 változó került be. Az egyes tételek a pesszimizmusra, elégedettség-örömképesség hiányára, önvádlásra, szociális visszahúzódásra, döntésképtelenségre, munkaképtelenségre, alvászavarra, fáradékonyságra, illetve a testi tünetekre vonatkozó túlzott aggodalomra vonatkoznak [36]. A magasabb összpontszám súlyosabb depressziós tünetegyüttest jelez. A rövidített skála megbízhatósági koefficiense 0,83 [35], amit a vizsgálatunkban megerősítettünk: 0,82 .

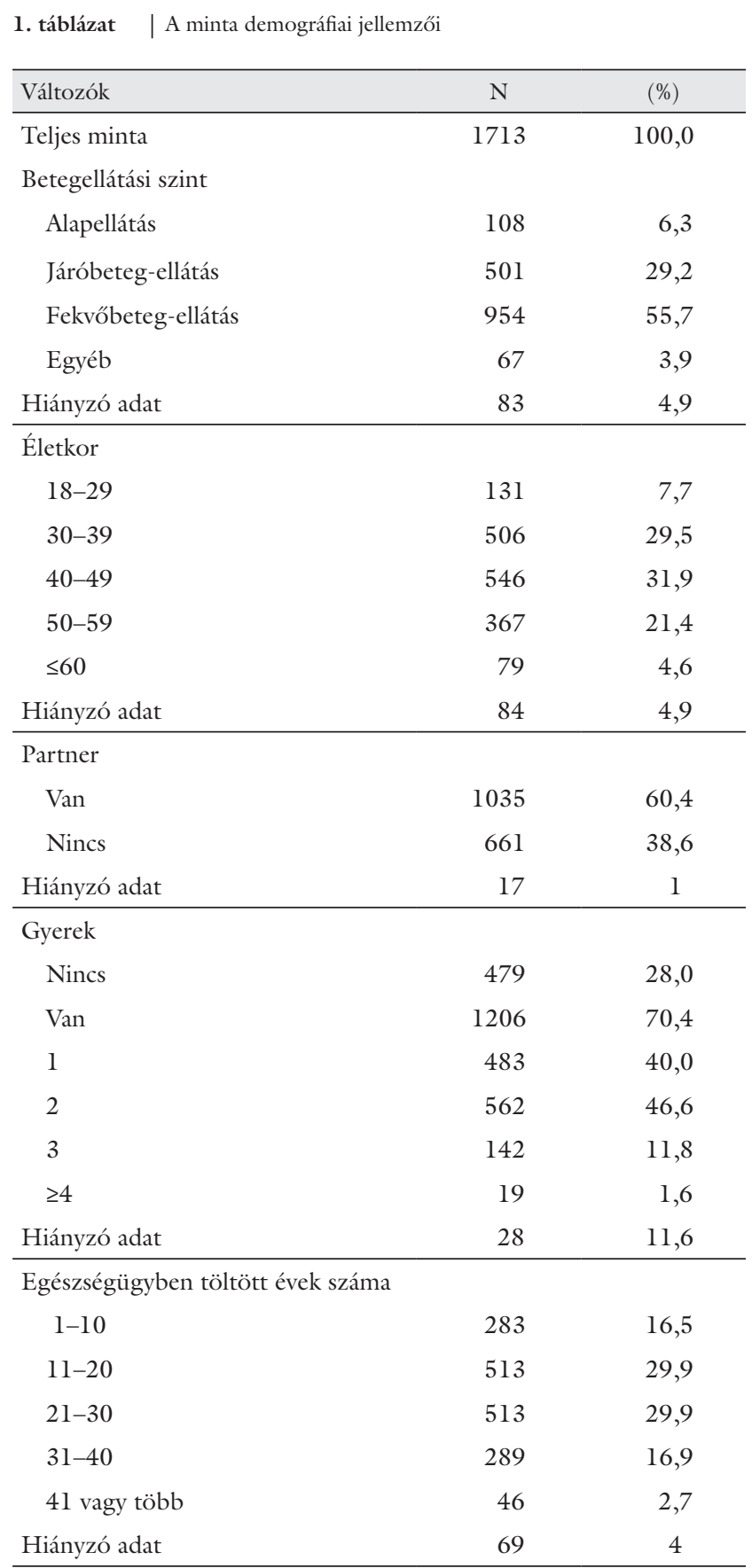

\section{Statisztikai elemzés}

Leíró statisztikai módszereket használtunk a minta leírásához (átlag, szórás, arány). A folytonos változók esetén a csoportok átlagai közötti különbségeket független mintás $t$-teszttel, illetve varianciaelemzéssel, a kategóriás változók esetén a csoportok arányai közötti különbségeket $\chi^{2}$-teszttel vizsgáltuk. Az adatok elemzését SPSS 20.0 szoftverrel végeztük. A szignifikancia szintjét $p<0,05$ ban állapítottuk meg. 
2. táblázat | A kiégés és a depressziós tünetek prevalenciája egészségügyi szakdolgozók körében (N=1713)

\begin{tabular}{|c|c|c|c|c|c|}
\hline Mért változó & Súlyos/magas szintű & $\begin{array}{l}\text { Közepesen súlyos/ } \\
\text { közepes szintű }\end{array}$ & Enyhe/alacsony szintü & Nincs & Hiányzó adat \\
\hline \multirow[t]{2}{*}{ Depressziós tünetek N (\%) } & 85 & 126 & 375 & 1082 & $45(2,6)$ \\
\hline & $(5,0)$ & $(7,3)$ & $(21,9)$ & $(63,2)$ & \\
\hline \multicolumn{6}{|l|}{ Kiégés N (\%) } \\
\hline Emocionális kimerültség & $349(21,7)$ & $361(22,4)$ & $902(56,0)$ & & $120(5,9)$ \\
\hline Deperszonalizáció & $264(16,5)$ & $303(18,9)$ & $1035(64,6)$ & & $130(6,5)$ \\
\hline Személyes teljesítményérzés hiánya & $759(49,1)$ & $382(24,7)$ & $404(26,1)$ & & $187(9,8)$ \\
\hline
\end{tabular}

3. táblázat A kiégés és a depressziós tünetek prevalenciája azon egészségügyi szakdolgozók körében, akiket életük során már kezeltek pszichés megbetegedéssel $(\mathrm{N}=166)$

\begin{tabular}{lllll}
\hline Mért változó & Súlyos/magas szintű & $\begin{array}{l}\text { Közepesen súlyos/ } \\
\text { közepes szintú }\end{array}$ & Enyhe/alacsony szintű Nincs & Hiányzó adat \\
\hline Depressziós tünetek N (\%) & $22(13,3)$ & $19(11,4)$ & $37(22,3)$ & $88(53)$ \\
\hline $\begin{array}{l}\text { Kiégés N (\%) } \\
\text { Emocionális kimerültség }\end{array}$ & $48(28,9)$ & $46(27,7)$ & $65(39,2)$ & $22(13,3)$ \\
Deperszonalizáció & $99(59,6)$ & $36(21,7)$ & $28(16,9)$ & $9(5,4)$ \\
Személyes teljesítményérzés hiánya & $84(50,6)$ & $45(27,1)$ & $9(5,4)$ \\
\hline
\end{tabular}

\section{Eredmények}

\section{A kiégés és a depressziós tünetek prevalenciája az egészségügyi szakdolgozók körében magas}

Mivel az MBI-HSS-nek nincsenek magyar mintán leírt határértékei, ezért a Maslach, Jackson és Leiter [31] által közölt, amerikai mintán meghatározott határértékeket használtuk az alacsony, közepes és magas szintű kiégésben szenvedők arányának a megállapításához. Bár magyar mintán a kiégés három dimenzión elért összpontszáma és a személyes teljesítmény dimenzió értéke a mérvadó, jelen elemzésünk kitért az emocionális kimerültség és a deperszonalizáció dimenziók elemzésére is. Ennek célja az, hogy elősegítsük az eredmények összehasonlíthatóságát más vizsgálatokkal.

A 2. táblázatból látható, hogy az általunk vizsgált egészségügyi szakdolgozók közül 5,1\% küzd súlyos depressziós tünetekkel és körülbelül egyharmaduknak $(35,1 \%)$ van legalább enyhe szintű depressziós tünete. A vizsgálatban résztvevők közül 20,3\%, 15,4\% és 44,3\% számolt be egyenként magas szintû emocionális kimerültségrőll, deperszonalizációról és a teljesítményérzés hiányáról. A szakdolgozók több mint felére jellemző a legalább közepes szintű emocionális kimerültség és a deperszonalizáció, továbbá közel háromnegyede tapasztalt legalább közepes mértékű teljesítményérzés-hiányt $(66,8 \%)$. Mivel magyar mintán az emocionális kimerüléssel és a deperszonalizációval szemben a személyes teljesítményérzés hiányának fontos prediktív szerepe lehet [30], a kiégés rizikó- és védőtényezőinek további vizsgálatához ezt a dimenziót vettük figyelembe.

\section{A korábbi pszichés megbetegedés a kiégés és a depresszió rizikótényezôje}

Vizsgálatunk figyelemre méltó eredménye, hogy azok között a szakdolgozók között, akiket életük során már kezeltek pszichés megbetegedésekkel $(\mathrm{N}=166)$, a magas szintű emocionális kimerültség, a deperszonalizáció és a súlyos depressziós tünetek prevalenciája többszörösére emelkedett (3. táblázat) azokhoz képest, akiket nem kezeltek pszichés megbetegedéssel (4. táblázat). Az emelkedés a súlyos depressziós tüneteket jelentők körében volt a legmagasabb (közel négyszeres). Első hipotézisünk tehát beigazolódott. Érdekes adat, hogy a magas szintû teljesítményérzés hiányának prevalenciáját a korábbi pszichiátriai megbetegedés jelenléte nem befolyásolta (3. és 4. táblázat).

\section{Hasonló a depressziós tünetek prevalenciája és szintje a férfi és nôi egészségügyi dolgozók körében}

Második hipotézisünk értelmében a nóknél magasabb értéket vártunk a depressziós tünetek gyakoriságában és szintjében a férfiakéhoz képest. Figyelembe véve a nők túlnyomó arányát a mintában (egy szempontos varianciaanalízis robusztus változatát alkalmazva), a prevalencia különbségeinek tesztelésére khi-négyzet próbát alkalmaztunk. A depresszió egyes szintjeit, valamint a klinikai szintű depresszióként aposztrofált közepes és súlyos depressziót is vizsgáltuk nemi bontásban. Eredményeink azt mutatták, hogy a nők és a férfiak között a depresszió pre- 
4. táblázat A kiégés és a depressziós tünetek prevalenciája azon egészségügyi szakdolgozók körében, akiket életük során soha nem kezeltek pszichés megbetegedéssel $(\mathrm{N}=1433)$

\begin{tabular}{|c|c|c|c|c|c|}
\hline Mért változó & Súlyos/magas szintű & $\begin{array}{l}\text { Közepesen súlyos/ } \\
\text { közepes szintû }\end{array}$ & Enyhe/alacsony szintű & Nincs & Hiányzó adat \\
\hline Depressziós tünetek N (\%) & $59(4,1)$ & $98(6,8)$ & $309(21,6)$ & $927(64,7$ & $40(2,8)$ \\
\hline \multicolumn{6}{|l|}{ Kiégés N (\%) } \\
\hline Emocionális kimerültség & $274(19,1)$ & $294(20,5)$ & $782(54,6)$ & & $83(5,8)$ \\
\hline Deperszonalizáció & $221(15,4)$ & $246(17,2)$ & $878(61,3)$ & & $88(6,1)$ \\
\hline Személyes teljesítményérzés hiánya & $633(44,2)$ & $316(22,0)$ & $345(24,1)$ & & $139(9,7)$ \\
\hline
\end{tabular}

valenciájában nincs szignifikáns különbség sem a klinikai szuntü depressziót tekintve, sem pedig a depresszió egyes szintjein. (5. táblázat). A depressziós tünetek szintjét illetően sem találtunk nemi különbséget a nők és a férfiak között (egyenként 9,8 [SD 8,5] és 8,8 [SD 8,8], $t[\mathrm{df}]=-0,1[4], p=$ A prevalencia különbségeinek tesztelésére khi-négyzet próbát alkalmaztunk. A depresszió egyes szintjeit, valamint a klinikai szintű depresszióként aposztrofált közepes és súlyos depressziót is vizsgáltuk nemi bontásban.1,0), ami enyhe szintû depressziós tüneteket jelez. Második hipotézisünk a depressziós tünetek prevalenciájának és szintjének nemi különbségeiről tehát nem igazolódott be.

\section{A férfiak körében szignifikánsan magasabb a deperszonalizáció (kiégés) szintje és prevalenciája a nőkhöz képest}

Második hipotézisünk felvetette a kiégés prevalenciájának és szintjének nemi különbségét. Mindössze a deperszonalizáció szintjében találtunk nemi különbséget. A többi dimenzióban, valamint a kiégés összpontszámában mindkét nem hasonló szintű kiégést mutatott (6. táblázat). A kiégés prevalenciáját illetően azt találtuk, hogy a férfiak - alacsony elemszámuk ellenére - szignifikánsan gyakrabban számoltak be legalább közepes, illetve magas szintû́ deperszonalizációról, mint a nők (7. táblázat). Eredményeink alapján második hipotézisünk (a kiégés és depresszió nők körében magasabb prevalenciájáról és szintjérôl a férfiakéhoz képest) nem igazolódott be.

\section{A partner és a gyerek megléte, a hosszabb, valamint a járóbeteg-ellátásban való munkaviszony a kiégés pédōtényezői, mig a partner hiánya a depressziós tünetek kockázati tényezóje}

A kiégés és a depressziós tünetek lehetséges védő- és rizikótényezőinek feltárásához a kiégés összpontszámának és a személyes teljesítmény, valamint a depressziós tünetek pontszámának átlagértékeiben megfigyelt változásokat elemeztük a demográfiai és munkahelyi tényezők függvényében (8. táblázat). Varianciaanalíziseink ered- ményei azt mutatták, hogy a kiégés szempontjából a legjobb helyzetben azok vannak, akiknek van partnere, szemben azokkal, akiknek nincs. A partnerkapcsolatban élők ritkábban jelentenek depressziós tüneteket, azonban a depressziós panaszok száma azoknál a legmagasabb, akik elvesztették vagy elváltak partnerüktől. Kevésbé számolnak be kiégésről és hatékonyabbnak érzik magukat azok, akiknek van gyereke, azokhoz képest, akiknek nincs. Depressziós tünetek szempontjából azonban nincs jelentősége a gyermekek számának. Így harma-

5. táblázat $\mid$ Nemi különbségek a depressziós tünetek prevalenciájában egészségügyi szakdolgozók körében $(\mathrm{N}=1713)$

\begin{tabular}{|c|c|c|c|}
\hline & $\begin{array}{l}\text { Nők } \\
\text { N=1634 }\end{array}$ & $\begin{array}{l}\text { Férfiak } \\
\mathrm{N}=79\end{array}$ & $\begin{array}{l}\text { Különböző- } \\
\text { ségi teszt (df) }\end{array}$ \\
\hline Mért változó & Gyakoriság (\%) & Gyakoriság (\%) & \\
\hline \multicolumn{4}{|l|}{ Depressziós tünetek } \\
\hline $\begin{array}{l}\text { Közepesen súlyos } \\
\text { és súlyos együtt }\end{array}$ & $198(12,1)$ & $9(11,4)$ & Nsz \\
\hline Enyhe szintû & $349(21,4)$ & $18(22,8)$ & Nsz \\
\hline $\begin{array}{l}\text { Közepesen súlyos } \\
\text { szintű }\end{array}$ & $121(7,4)$ & $4(5,1)$ & Nsz \\
\hline Súlyos szintű & $77(4,7)$ & $5(6,3)$ & Nsz \\
\hline
\end{tabular}

Nsz: Nem szignifikáns.

6. táblázat $\mid$ Nemi különbségek a kiégés szintjében egészségügyi szakdolgozók körében ( $\mathrm{N}=1540)$

\begin{tabular}{llll}
\hline Mért változó & $\begin{array}{l}\text { Nők, } \\
\text { átlag (SD) }\end{array}$ & $\begin{array}{l}\text { Férfiak, } \\
\text { átlag }(\mathrm{SD})\end{array}$ & $\begin{array}{l}\text { Különbözőségi } \\
\text { teszt }(\mathrm{df})\end{array}$ \\
\hline Kiégés & $37,3(19,0)$ & $40,5(22,8)$ & $t=1,2(75)^{\mathrm{a}}$ \\
$\begin{array}{l}\text { Személyes } \\
\text { teljesítmény- } \\
\text { csökkenés } \\
(\mathrm{N}=1540)\end{array}$ & $32,8(8,9)$ & $31,8(10,7)$ & $t=-0,8(77)^{\mathrm{a}}$ \\
$\begin{array}{l}\text { Érzelmi kimerülés } \\
\text { (N=1612) }\end{array}$ & $18,1(12,1)$ & $18,1(12,1)$ & $t=0,1(76)^{\mathrm{a}}$ \\
$\begin{array}{l}\text { Deperszonalizáció } \\
(\mathrm{N}=1602)\end{array}$ & $4,7(5,1)$ & $7,1(6,6)$ & $t=3,0(77)^{* *}$ \\
\hline
\end{tabular}

${ }^{*} p<0,05 ;{ }^{*}{ }^{*} p<0,01 ; * * * p<0,001$

${ }^{a}$ Nem szignifikáns. 
7. táblázat | Nemi különbségek a kiégés gyakoriságában egészségügyi szakdolgozók körében

\begin{tabular}{llll}
\hline & Nók, & Férfiak, & $\begin{array}{l}\text { Különböző- } \\
\text { ségi teszt }(\mathrm{df})\end{array}$ \\
\hline Kiégés & $\begin{array}{l}\text { Gyakoriság } \\
(\%)\end{array}$ & Gyakoriság $(\%)$ & \\
& & & \\
\hline
\end{tabular}

Emocionális
kimerültség

\begin{tabular}{llll}
$\begin{array}{l}\text { Közepes és magas } \\
\text { szintű együtt }\end{array}$ & $670(41,0)$ & $33(41,8)$ & $\chi^{2}=0,1(1)^{\mathrm{a}}$ \\
$\begin{array}{l}\text { Alacsony szintű } \\
\text { Közepes szintű }\end{array}$ & $343(21,0)$ & $17(21,5)$ & \\
$\begin{array}{l}\text { Magas szintű } \\
\text { Deperszonalizáció }\end{array}$ & $327(20,0)$ & $16(20,2)$ & $\chi^{2}=0,2(1)^{\mathrm{a}}$ \\
\hline $\begin{array}{l}\text { Közepes és magas } \\
\text { szintű együtt }\end{array}$ & $520(31,8)$ & $37(46,8)$ & $\chi^{2}=7,5(1)^{* *}$ \\
$\begin{array}{l}\text { Alacsony szintű } \\
\text { Közepes szintű }\end{array}$ & $284(17,4)$ & $15(19,0)$ & \\
Magas szintű & $236(14,4)$ & $22(27,8)$ & $\chi^{2}=10,3(1)^{* * *}$ \\
\hline
\end{tabular}

Személyes

teljesítményérzés

hiánya

$\begin{array}{lccc}\begin{array}{l}\text { Közepes és magas } \\ \text { szintű együtt }\end{array} & 1075(65,8) & 51(64,6) & \chi^{2}=0,6(1)^{\mathrm{a}} \\ \begin{array}{l}\text { Alacsony szintű } \\ \text { Közepes szintű }\end{array} & 367(22,2), 5) & 12(15,2) & \\ \text { Magas szintű } & 708(43,3) & 39(49,4) & \chi^{2}=0,6(1)^{\mathrm{a}}\end{array}$

${ }^{*} p<0,05 ;{ }^{*}{ }^{*} p<0,01 ; * * * p<0,001$

${ }^{a}$ Nem szignifikáns.

dik és negyedik hipotézisünk teljes mértékben beigazolódott. Ötödik hipotézisünkben feltételeztük azt is, hogy a kiégés szintje alacsonyabb azok körében, akiknek hoszszabb egészségügyi munkaviszonyuk van. Eredményeink alátámasztják ezt a feltevésünket. A több mint harminc éve az egészségügyben dolgozók kiégettsége szignifikánsan alacsonyabb a kevesebb ideje ott dolgozókhoz képest. Hatodik hipotézisünkben az életkor és a depreszsziós tünetek közötti egyenes arányú kapcsolatot tételeztük fel, azonban a magasabb életkor nem járt több depressziós tünettel. Érdekes eredmény, hogy a magasabb életkorúak (ötven év fölöttiek) alacsonyabb szintű kiégésről számolnak be. Eredményeink azt is mutatják, hogy a fekvő- és a járóbeteg-ellátásban dolgozók között van a legnagyobb különbség a kiégés szintjében. A fekvőbeteg-ellátásban dolgozók magasabb kiégést és alacsonyabb személyes teljesítményérzést jeleztek, mint a járóbeteg-ellátásban dolgozó szakemberek. Érdekes azonban, hogy depressziós tünetek tekintetében viszont a járó betegeket kezelők mutatnak magasabb szintet, bár depressziós tüneteik mértéke mindössze az egészségügy egyéb területein (például gyógyszertári asszisztensek, otthon ápolással foglalkozók) dolgozókhoz képest szignifikáns (8. táblázat).

\section{Megbeszélés}

A klinikai gyakorlatban elméletileg találkozhatunk a kiégés és a depresszió tiszta, izolált formájával, de az esetek túlnyomó többségében a két kórállapot határvonalai

\section{8. táblázat $\mid$ A depressziós tünetek és kiégés manifesztációja egészségügyi szakdolgozók körében a munkahelyi és demográfiai változók függvényében}

\begin{tabular}{|c|c|c|c|}
\hline $\begin{array}{l}\text { Demográfiai/munkahelyi } \\
\text { tényezők }\end{array}$ & $\begin{array}{l}\text { Kiégés, } \\
\text { átlag (szórás) }\end{array}$ & $\begin{array}{l}\text { Személyes } \\
\text { teljesítmé- } \\
\text { nyérzés } \\
\text { hiánya, } \\
\text { átlag } \\
\text { (szórás) }\end{array}$ & $\begin{array}{l}\text { Depresszi- } \\
\text { ós tünetek, } \\
\text { átlag } \\
\text { (szórás) }\end{array}$ \\
\hline
\end{tabular}

Betegellátás formája

$\begin{array}{llll}\text { Alap } & 33,4(18,8) & 34,4(8,4) & 8,1\end{array}(8,8)$

Járó $\quad 36,1(19,9) \quad 33,2(8,9) \quad 9,6(9,6)$

Fekvő $\quad 39,3(18,9) \quad 32,0(9,1) \quad 8,8(7,9)$

Egyéb 31,6 (18,1) 34,3 $\quad 3,9,5) \quad 6,3(7,0)$

F-érték $6,8^{*} \quad 4,2$ ** $3,7^{*}$ *

Családi állapot

Hajadon $\quad 41,1(21,3) \quad 31,2(9,1) \quad 8,89(8,4)$

Van partnere $\quad 36,2(18,6) \quad 33,0(8,9) \quad 8,3(8,1)$

Elvesztette partnerét $\quad 38,5(19,2) \quad 33,1(9,3) \quad 10,4(9,3)$

(válás, halál)

F-érték 6,9 ** 4,4 ** 8,0 ***

Gyerekek száma

Nincs gyermek $\quad 40,3(20,0) \quad 31,3(9,4) \quad 8,7(8,2)$

$\begin{array}{llll}\text { Egy gyermek } \quad 37,5(19,0) & 32,4(9,3) \quad 9,2(8,8)\end{array}$

Két gyermek $\quad 35,6(19,1) \quad 33,8(8,6) \quad 8,8(8,6)$

Három vagy több $\quad 33,3(17,4) \quad 34,1(8,3) \quad 8,1(8,6)$

gyermek

\begin{tabular}{llll} 
F-érték & $8,1^{* * *}$ & $7,3^{* * *}$ & $0,8^{a}$ \\
\hline Életkor & & & \\
Húszas éveiben jár & $39,0(18,0)$ & $32,4(8,2)$ & $7,7(7,2)$ \\
Harmincas éveiben jár & $40,3(20,1)$ & $31,5(8,9)$ & $8,8(8,8)$ \\
Negyvenes éveiben jár & $39,4(19,6)$ & $32,0(9,1)$ & $9,3(8,9)$ \\
Ötvenes éveiben jár & $32,6(16,4)$ & $34,8(8,9)$ & $9,0(8,0)$ \\
Hatvanas, hetvenes & $27,5(18,1)$ & $37,7(7,4)$ & $8,6(8,4)$ \\
éveiben jár. & & & \\
F-érték & $13,9^{* * *}$ & $13,1^{* * *}$ & $1,0^{a}$ \\
\hline
\end{tabular}

Egészségügyben töltött

évek száma

$\begin{array}{lcll}1-10 & 38,7(18,6) & 32,2(8,8) & 8,4(8,0) \\ 11-20 & 39,4(20,3) & 31,96(8,9) & 8,7(9,0) \\ 21-30 & 38,6(19,4) & 32,1(9,2) & 9,4(8,7) \\ 31-40 & 33,1(16,1) & 34,8(8,5) & 9,1(7,7) \\ 41 \text { vagy a feletti } & 28,1(19,4) & 36,8(7,8) & 7,4(7,9) \\ \text { F-érték } & 7,3^{* * *} & 6,8^{* * *} & 1,1^{\text {a }}\end{array}$

${ }^{*} p<0,05 ;{ }^{*}{ }^{*} p<0,01 ; * * * p<0,001$

a Nem szignifikáns. 
nem különülnek el világosan, és diagnosztizálásuk nehézségbe ütközik. Vegyünk példaként egy olyan embert, akinek nagy a felelősségtudata és perfekcionista. Munkáját magas színvonalon ellátja, így egyre több munkatársa és felettese kér tőle segítséget és számít rá a feladatok gyors és precíz megoldásában. Előbb-utóbb a munkahelyi követelmények meghaladják az egyén erőforrásait és kialakul a kiégés állapota. Azt várnánk, hogy ha elküldjük betegszabadságra a munkából, akkor megszúnik a streszsz és a kiégés elmúlik. Azonban az egyén személyes kudarcként éli át a helyzetet, mert úgy érzi, hogy cserbenhagyta munkatársait és feletteseit. Az inkompetencia érzése reaktív és rosszabb esetben klinikai depresszióhoz vezethet. Ez a példa jól szemlélteti a gyakorló orvos vagy pszichológus diagnosztikus és terápiás kihívásait.

Jelen tanulmányunk elsődleges célja az volt, hogy a gyakorló szakemberek számára elősegítsük a kiégés és a depresszió mihamarabbi felismerését a két kórállapot demográfiai és munkahelyi védő- és rizikótényezőinek a feltárásával. Eredményeink azt mutatják, hogy a depreszsziós tünetek nagyobb valószínúséggel fordulnak elő azoknál, akiknek volt korábban pszichés megbetegedése és akiknek nincs partnerük. A kiégés prevalenciája nagyobb volt azon férfiak körében, akiknek korábban pszichés betegségük volt. A kiégés védőtényezőinek bizonyultak a partner és a gyerek megléte, a hosszabb munkaviszony és a járóbeteg-ellátásban való foglalkoztatottság.

Vizsgálatunkban magas szintű pszichés morbiditást találtunk az egészségügyi dolgozók körében. Közel egyharmaduknak $(35,1 \%)$ volt legalább enyhe szintü depressziós tünete. Ezek az eredmények összhangban vannak azon hazai kutatásokkal, amelyek igazolják: az egészségügyben dolgozók 24-45\%-a éri el az önbeszámolós teszttel mérhető depresszió szintjét [26]. A Hungarostudy 2002 eredményei azt mutatják, hogy a mentális egészség tekintetében a terminális betegekkel foglalkozó egészségügyi dolgozók vannak a legrosszabb helyzetben, több közöttük az egyedülálló, a depressziós, valamint öngyilkossági gondolataik is gyakoribbak [37]. A terminális betegekkel dolgozók mellett az onkológián, a pszichiátrián, valamint a mozgásszervi rehabilitációval, fiatal, traumatizált betegek kezelésével foglalkozók körében a legmagasabb a depressziósok aránya [38, 39]. Egy nemrég végzett vizsgálat azt mutatta, hogy a depressziós tünetek prevalenciája amerikai kórházi ápolók körében 18\% volt, ami duplája a normatív populációban mértnek [40]. Az ápolók körében a depresszió a munkahelyi elégedettséggel, a betegségek számával és a pszichés jólléttel volt szoros kapcsolatban. Ezek az eredmények alátámasztják a stressz és más pszichés morbiditás lehetséges szerepét a depresszió patogenezisében. Mivel a magyar egészségügyi szakdolgozók körében magas a stressz prevalenciája, feltételezhető, hogy a magas depresszió hátterében ez állhat [7].

Eredményeink azt mutatják, hogy a szakdolgozók több mint felére jellemző a legalább közepes szintű emo- cionális kimerültség és a deperszonalizáció, továbbá közel háromnegyede tapasztalt legalább közepes mértékü teljesítményérzés-hiányt $(73,8 \%)$. Jelen eredményeink megegyeznek az orvosok körében megfigyelt személyes teljesítményérzés hiányának kiemelten magas prevalenciájával [30], és megerősítik azt a hipotézist, miszerint a magyar egészségügyi dolgozók között a kiégés kialakulásában a személyes teljesítményérzés hiánya - a másik két dimenzió mellett vagy helyett - fontos szerepet tölthet be [32]. A magyar egészségügyi szakdolgozók körében a kiégés jelen vizsgálatunkban leírt prevalenciája más országokban dolgozó szakdolgozókhoz képest is magas. Ezek a nemzetközi tanulmányok 30-80\%-os prevalenciáról számoltak be [41]. A kiégés nemzetközi összehasonlításban is magas prevalenciájának hátterében a magyar szakdolgozók magasabb munkahelyi stressz-szintje húzódhat meg. A magasabb stressz okát a magas munkahelyi követelményekben, az alacsony kontrollban és a társas támogatás hiányában kell keresnünk, amihez az aránytalanul alacsony anyagi kompenzáció társul. Ezeket a hipotéziseket további vizsgálatokkal kell megerősíteni.

Vizsgálatunk egyik fontos eredménye az volt, hogy azok között a szakdolgozók között, akiket életük során már kezeltek pszichés megbetegedésekkel, a magas szintü kiégés (emocionális kimerültség és a deperszonalizáció), valamint a súlyos depressziós tünetek prevalenciája a többszöröse volt azokhoz képest, akiket nem kezeltek pszichés megbetegedéssel. Ez az eredmény két fontos hipotézist vet fel: Az egyik az, hogy a már meglévő pszichés megbetegedés hajlamosít a kiégés és depresszió fellépésére és szintjének súlyosbítására, a másik pedig az, hogy a kiégés és depresszió tünetegyüttese egymással egyidejúleg lép fel és változik. Ez utóbbi megfigyelés azt jelentheti, hogy a kiégés és a depresszió ugyanannak a jelenségnek a manifesztációja, vagyis a kiégés „munkahelyi depressziónak" tekinthető. Ezt a felvetést támogatja Abola és munkatársainak (2014) nem régi longitudinális, a tünetek dinamizmusát nyomon követő tanulmánya, amelyben azt figyelték meg, hogy a kiégés és a depresszió tünetei az évek folyamán egyidejúleg és egyformán változnak, valamint alakulnak ki [2]. Vizsgálatunkban a kiégés személyes teljesítményérzés hiányát mutató értéke magas maradt a már pszichés betegségekkel kezelt és nem kezelt csoportban. Ez a megfigyelés és korábbi kutatási adataink a személyes teljesítmény értékelésének kiemelten fontos - a másik két dimenziótól független szerepére utalhat a kiégés patomechanizmusában [30].

Vizsgálatunkban - hipotézisünkkel ellentétben - nem találtunk nemi különbséget a depresszió prevalenciájában és szintjében, annak ellenére, hogy a nók depressziópontszáma magasabb volt a férfiakéhoz képest. Ez ellentétben áll a hazai és nemzetközi szakirodalommal, miszerint a depresszió nagyobb arányban fordul elő nőknél, mint férfiaknál $[15,16]$. Ennek oka kereshető az elemszámok, illetve a válaszadási hajlandóság különbségeiben, valamint a depresszió növekvő gyakoriságában férfiak körében [42]. Eredményeink a férfiak szignifikán- 
san magasabb szintű deperszonalizációjáról megerősítik azt az általánosan elfogadott nézetet, miszerint a férfiak stresszkezelő stratégiái előnyben részesítik a helyzetekból való kivonódást, ami gyakran deperszonalizációhoz vezet [17].

Kutatásunk során beigazolódott, hogy azok az egészségügyi dolgozók, akiknek partnere és gyereke van, alacsonyabb kiégéspontszámot mutatnak. A partner elvesztése viszont nem befolyásolja a kiégést. Ellenben azok, akik elvesztették partnerüket (válás/haláleset) több depresszív tünetról számolnak be. Eredményeink megegyeznek azokkal a nemzetközi szakirodalmi adatokkal, amelyek arra utalnak, hogy a depresszió lényeges kiváltó tényezője lehet a házastárs vagy családtag elvesztése [18, 43]. Adataink megerósítik azokat a vizsgálati eredményeket, amelyek azt mutatják, hogy azok a munkavállalók, akiknek házastársa, gyermeke van, kevésbé szenvednek kiégéstől [19, 20].

Az orvosokhoz hasonlóan, az egészségügyi szakdolgozók kiégését és depresszióját a munkahelyi tényezők nagymértékben befolyásolják. Eredményeink azt mutatják, hogy aki hosszabb egészségügyi munkaviszonnyal rendelkezik, ritkábban szenved kiégéstől ahhoz képest, aki rövidebb munkaviszonnyal bír. A depresszió esetében nem találtunk kapcsolatot az idősebb életkor és a depressziós tünetek megemelkedett szintje között. Ennek valószínúleg az az oka, hogy azok a vizsgálatok, amelyek szerint a depresszió idősebb korban gyakoribb, elsősorban epidemiológiai vizsgálatok, amelyek a populáció egészére vonatkozó reprezentatív mintából vonnak le következtetéseket [16, 22]. Fontos megemlíteni, hogy ennek hátterében állhat a már említett „healthy worker effect” [21], miszerint az idősebbek közül azok vesznek szívesebben részt önkitöltős vizsgálatokban, akik mentálisan egészségesebbek, s ez magyarázhatja azt is, hogy alacsonyabb körükben a kiégés és a depresszió prevalenciája. Vizsgálatunk eredményei azt mutatják, hogy a fekvőbeteg-ellátásban dolgozók magasabb kiégésről és alacsonyabb személyes teljesítményérzésről számolnak be, mint a járóbeteg-ellátásban dolgozó szakemberek. A járóbeteg-ellátásban való munkaviszony azonban a depresszió rizikótényezője lehet. Ezt az eredményt további vizsgálatokkal szükséges megerősíteni. Eredményeink igazolják azokat a magyarországi adatokat, miszerint az akut, fekvőbeteg-ellátásban dolgozó nővérek - például a sürgősségi és intenzív osztályon dolgozók - körében a kiégés prevalenciája magasabb, mint a krónikus vagy járóbeteg-ellátásban dolgozóké [38, 39].

Kutatásunk egyik gyenge pontja az, hogy keresztmetszeti vizsgálat, így ok-okozati viszonyokat nem lehet felállítani. A tényleges ok-okozati összefüggések kimutatásához longitudinális vizsgálatra lenne szükség. További korlátot jelent, hogy vizsgálatunk nem reprezentatív az egészségügyi szakdolgozókra nézve, mivel az adatfelvétel központja Budapest volt, ezért a vizsgálatban résztvevők többsége a fővárosban, illetve a fővároshoz közeli településeken él. A gyengeségek mellett számos erösség is jellemzi tanulmányunkat. Magyar viszonylatban elsőként számolunk be a depresszió és a kiégés közötti kapcsolat vizsgálatáról, és kutatásunk számos érdekes hipotézist vet fel a két kórállapot esetleges azonosságáról. A vizsgálat további előnye a nagy minta.

\section{Következtetések}

Elmondható, hogy a vizsgálatunkban feltárt betegségspecifikus védő- és rizikótényezők ismerete elősegítheti a kiégés és a depresszió diagnosztizálását egészségügyi szakdolgozók körében, ami javíthatja a kezelés hatásosságát és az egészségügyi szakdolgozók pszichés jóllétét, valamint közvetve a betegellátás hatékonyságát.

Anyagi támogatás: A közlemény megírása anyagi támogatásban nem részesült.

Szerzôi munkamegosztás: Á. Sz.: Az alapkoncepció kidolgozása, a kézirat megírása, javítása, megbeszélés. N. A.: A kézirat szerkesztése, szövegezése. N. K.: A kézirat szövegezése, az irodalom összeállítása. Cs. Z.: A kézirat szövegezése, adatgyüjtés. M. V.: A módszertan kidolgozása, statisztikai elemzés. A cikk végleges változatát valamenynyi szerző elolvasta és jóváhagyta.

Érdekeltségek: A szerzőknek nincsenek érdekeltségeik.

\section{Irodalom}

[1] Bakker, A. B., Schaufeli, W. B., Demerouti, E., et al.: Using equity theory to examine the difference between burnout and depression. Anxiety Stress Coping, 2000, 13, 247-268.

[2] Ahola, K., Hakanen, J., Perhoniemi, R., et al.: Relationship between burnout and depressive symptoms: a study using the person-centred approach. Burn. Res., 2014, 1(1), 29-37.

[3] Shirom, A., Ezrachi, .: On the discriminant validity of burnout, depression and anxiety: A re-examination of the burnout measure. Anxiety Stress Coping, 2003, 16(1), 83-97.

[4] Shirom, A., Melamed, S., Toker, S., et al.: Burnout, mental and physical health: A review of the evidence and a proposed explanatory model. Int. Rev. Ind. Organ. Psychol., 2005, 20, 269-309.

[5] Glass, D. C., McKnight, J. D., Valdimarsdottir, H.: Depression, burnout, and perceptions of control in hospital nurses. J. Consult. Clin. Psychol., 1993, 61(1), 147-155.

[6] Maslach, C., Schanfeli, W. B., Leiter, M. P.: Job burnout. Annu. Rev. Psychol., 2001. 52(1), 397-422.

[7] Mészáros, V., Cserháti, Z., Oláh, A., et al.: Coping with work-related stress in health care professionals - strategies for prevention of burnout and depression. [A munkahelyi stresszel való megküzdés egészségügyi szakdolgozók körében - lehetőségek a kiégés és depresszió megelőzésének szolgálatában.] Orv. Hetil., 2013, 154(12), 449-454.[Hungarian]

[8] Hidaka, B. H.: Depression as a disease of modernity: explanations for increasing prevalence. J. Affect. Disorders., 2012, 140(3), 205-214.

[9] Bonde, J. P.: Psychosocial factors at work and risk of depression: a systematic review of the epidemiological evidence. Occup. Environ. Med., 2008, 65(7), 438-445.

[10] Leiter, M. P., Durup, J.: The discriminant validity of burnout and depression: a confirmatory factor analytic study. Anxiety Stress Coping, 1994, 7(4), 357-373. 
[11] Kulcsár, Z.: Health psychology. [Egészségpszichológia.] ELTE Eötvös Kiadó, Budapest, 1998. [Hungarian]

[12] Houkes, I., Winants, Y. H., Twellaar, M.: Specific determinants of burnout among male and female general practitioners: A crosslagged panel analysis. J. Occup. Organ. Psychol., 2008, 81(2), 249-276.

[13] Moreno-Jiménez, B., Rodrígez-Carvajal, R., Hernández, E. G., et al.: Terminal versus non-terminal care in physician burnout: the role of decision-making processes and attitudes to death. Salud Mental, 2008, 31(2), 93-101.

[14] Brenninkmeyer, V., Van Yperen, N. W., Buunk, B. P.: Burnout and depression are not identical twins: is decline of superiority a distinguishing feature? Pers. Individ. Dif., 2001, 30(5), 873-880.

[15] Nolen-Hoeksema, S., Larson, J., Grayson, C.: Explaining the gender difference in depressive symptoms. J. Pers. Soc. Psychol., 1999, 77(5), 1061-1072.

[16] Culbertson, F. M.: Depression and gender: an international review. Am. Psychol., 1997, 52(1), 25-31.

[17] Purvanova, R. K., Muros, J. P.: Gender differences in burnout: A meta-analysis. J. Vocat. Behav., 2010, 77(2), 168-185.

[18] Paykel, E. S.: Life events and affective disorders. Acta Psychiatr. Scand. Suppl., 2003, 108(S418), 61-66.

[19] Alacacioglu, A., Yavuzsen, T., Dirioz, M., et al.: Burnout in nurses and physicians working at an oncology department. Psychooncolgy, 2009, 18(5), 543-548.

[20] Dickinson-Bannack, M. E., González-Salinas, C., FernándezOrtega, M. A., et al.: Burnout syndrome among Mexican primary care physicians. Arch. Med. Fam., 2007, 9(2), 75-79.

[21] Ahola, K., Honkonen, T., Isometsä, E., et al.: Burnout in the general population. Soc. Psychiatry Psychiatr. Epidemiol., 2006, $41(1), 11-17$

[22] Purebl, Gy., Kovács, M.: The association between depressive symptoms and physical illnesses, its impact on quality of life. In Kopp, M., Kovács, M. E. (eds.): Quality of life of the Hungarian population at the turn of the millennium. [A depressziós tünetegyüttes kapcsolata a testi betegségekkel, hatása az életminőségre In: A magyar népesség életminősége az ezredfordulón.] Semmelweis Kiadó, Budapest, 2006. [Hungarian]

[23] Martin, F., Poyen, D., Bouderlique, E., et al.: Depression and burnout in hospital health care professionals. Int. J. Occup. Environ. Health, 1997, 3(3), 204-209.

[24] McKnight, J. D., Glass, D. C.: Perceptions of control, burnout, and depressive symptomatology: a replication and extension. J. Consult. Clin. Psychol., 1995, 63(3), 490-494.

[25] Dégi, Cs. L., Balogh, P., Kopp, M., et al.: Depressive symptoms, negative life events and incidence of lifetime treatment of cancer in the Hungarian population. J. Cogn. Behav. Psychother., 2010, 10(1), 39-57.

[26] Weborvos: The nurse is also in need of nursing care. [Az ápoló is ápolásra szorul.] 2010,

[27] http://www.weborvos.hu/egeszsegpolitika/apolo_is_apolasra_ szorul/159916/; [Hungarian]

[28] Palfi, I., Nemeth, K., Kerekes, Zs., et al.: The role of burnout among Hungarian nurses. Int. J. Nurs. Pract., 2008, 14(1), 1925.

[29] Bencés, I.: Nurses and burnout. [Az ápolók és a kiégés.] Nővér, 2006, 19(3), 10-16. [Hungarian]

[30] Köbli, M., Nagy, L. Pálfiné Szabó, I.: Investigation of burnout syndorme among nurses. [Kiégés szindróma vizsgálata az ápolók körében.] Nővér, 2008, 21(6), 11-20. [Hungarian]
[31] Ádám, Sz., Györffy, Zs., Susánszky, É.: Physician burnout in Hungary: a potential role for work-family conflict. J. Health. Psychol., 2008, 13(7), 847-856.

[32] Maslach, C., Jackson, S. E., Leiter, M. P.: Maslach burnout inventory manual (3rd ed.). Consulting Psychologists Press, Palo Alto, 1996.

[33] Mészáros, V., Ádám, Sz., Szabó, M., et al.: The bifactor model of the Maslach Burnout Inventory-Human Services Survey (MBI-HSS) - An alternative measurement model of burnout. Stress Health, 2014, 30(1), 82-88.

[34] Beck, A. T., Beck, R. W.: Screening depressed patients in family practice. A rapid technic. Postgrad. Med., 1972, 52(6), 81-85.

[35] Beck, A. T., Ward, C. H., Mendelson, M., et al.: An inventory for measuring depression. Arch. Gen. Psychiatry, 1961, 4(6), 561571.

[36] Rózsa, S., Szádóczky, E., Füredi, J.: Psychometric properties of the Hungarian version of the shortened Beck Depression Inventory. [A Beck Depresszió Kérdő́ív rövidített változatának jellemzői hazai mintán.] Psychiatr. Hung., 2001, 16(4), 384-402. [Hungarian]

[37] Kopp, M., Szedmák S., Löke, J., et al.: The prevalence of depressive symptoms and its medical significance in the Hungarian population. [A depressziós tünetegyüttes gyakorisága és egészségügyi jelentősége a magyar lakosság körében.] Lege Artis Medicinae, 1997, 7(3), 136-144. [Hungarian]

[38] Hegedús, K., Riskó, A.: Physical and mental health of healthcare workers working with severly ill patients. In: Kopp, M., Kovács, M. E. (eds.): Quality of life of the Hungarian population at the turn of the millennium. [Súlyos betegekkel foglalkozó egészségügyi dolgozók testi és lelki állapota. In: A magyar népesség életminősége az ezredfordulón.] Semmelweis Kiadó, Budapest, 2006. [Hungarian]

[39] Hegedús, K., Szabó, N., Szabó, G., et al.: Are healthcare workers healthier? A comparative study (2002-2006). [Egészségesebbeke az egészségügyben dolgozók? Összehasonlító vizsgálat (20022006).] Nővér, 2008, 21(1), 3-9. [Hungarian]

[40] Hegedús, K. Á., Riskó, Mészáros, E.: Physical and mental health of healthcare workers working with severly ill patients. [A súlyos betegekkel foglalkozó egészségügyi dolgozók testi és lelkiállapota.] Lege Artis Medicinae, 2004, 14(11), 786-793. [Hungarian]

[41] Letvak, S., Rubm, C. J., McCoy, T.: Depression in hospital-employed nurses. Clin. Nurse Spec., 2012, 26(3), 177-182.

[42] Tay, W. Y., Earnest, A., Tan, S. Y., et al.: Prevalence of burnout among nurses in a community hospital in Singapore: A crosssectional study. Proc. Singapore Healtc., 2014, 23(2), 93-99.

[43] Kessler, R. C., Chiu, W. T., Demler, O., et al.: Prevalence, severity, and comorbidity of 12 -month DSM-IV disorders in the National Comorbidity Survey Replication. Arch. Gen. Psychiatry, 2005, 62(6), 617-627.

[44] Finlay-Jones, R., Brown, G. W.: Types of stressful life event and the onset of anxiety and depressive disorders. Psychol. Med., $1981,11(4), 803-815$

(Ádám Szilvia dr., Budapest, Nagyvárad tér 4., 1089 e-mail: adamszilvia@hotmail.com) 